\title{
A massa a levedar: a imagem de Angola e Moçambique no Diário de Miguel Torga
}

\section{A rising dough: The image of Angola and Mozambique in Miguel Torga's Diary}

LENKA Kroupová [133415@mail.muni.cz]

Masarykova univerzita, República Checa

\section{RESUMO:}

Neste artigo pretendemos focar as impressões de Angola e Moçambique, que o autor capturou nas páginas do seu Diário, cultivado entre 1932 e 1994. Torga, que viveu a parte crucial da sua adolescência no Brasil (1920-1925), a capinar, guardar gado e apanhar café na Fazenda de Santa Cruz, Minas Gerais, mostravase especialmente sensível às condições de opressão, falta de liberdade, intolerância e humilhação. Nesta linha, destacam reflexões que Torga dedicou ao antigo Portugal Ultramarino, aos contrastes do presente de Portugal, as guerras que estavam a atormentar os territórios da África Portuguesa, bem como ao processo de descolonização. Uma importante parte desta vertente foi criada como reação à viagem a Angola e Moçambique realizada em 1973. Por tanto, a partir da leitura das entradas diarísticas, esperamos fornecer indicações sobre o entendimento do processo de descolonização, respeito pela cultura e a transmissão de valores éticos vistos pelo aclamado poeta português.

\section{Palavras-chave:}

Miguel Torga; Diário; império colonial; guerra colonial; descolonização

\begin{abstract}
:
We intend to reflect in this article Miguel Torga's impressions from his travel to Angola and Mozambique which the author captured in his Diary, cultivated between 1932 and 1994. Torga, who lived an important part of his adolescence in Brazil (1920-1925), was especially sensitive to the conditions of oppression, lack of freedom, intolerance and humiliation. In this regard, we will see Torga pondering about the former Portuguese Empire, finding contrasts in the Portugal of his time, rejecting wars that plagued the territories of the Portuguese Africa, and commenting on the decolonization process. An important portion of this thematic strand was created during his trip to Angola and Mozambique in 1973. Therefore, we hope to provide hints about Torga's understanding of the decolonization process, cultural respect and transmission of ethical values based on his diary entries.
\end{abstract}

\section{KEYWORDS:}

Miguel Torga; Diary; colonial empire; colonial war; decolonisation

RECEBIDO 2015-8-30; ACEITE 2016-1-30 


\section{Nota introdutória}

Durante a leitura dos respetivos volumes do Diário torguiano, cultivado entre 1932 e 1994, misturam-se temas de diversa natureza. Um dos eixos temáticos da obra de Miguel Torga (1907-1995) que Isabel Vaz Ponce de Leão inclui no ciclo de "maceração", ocupa-se das questões sociais e políticas, do conceito de nação e de pertença a essa nação. Este eixo perpassa toda a criação literária do grande escritor português, não excetuando a sua obra magna que é o $D i$ ário. Nas suas páginas afloram interessantes alusões ao antigo Portugal Ultramarino, ilusões e desilusões vinculadas com a Era dos Descobrimentos, conflitos bélicos, políticos e sociais que arrasavam aqueles territórios, e, afinal, comentários do processo de descolonização que experimentavam as colónias portuguesas. Estas menções aparecem ao longo de todo o diário, porém foi a sua viagem a Angola e Moçambique que o autor empreendeu em 1973 e as impressões que lhe causou onde esta temática está em maior concentração. Pretendemos, portanto, explorar a ótica pessoal através da qual Miguel Torga percebe o contacto com Angola e Moçambique, tal como fica refletida nas páginas do seu Diário.

Para conseguir suporte ao levantamento do objetivo planeado, baseamo-nos na experiência acumulada dos autores no campo dos estudos torguianos. Neste caso, particularmente na de Isabel Vaz Ponce de Leão, estudiosa da obra diarística de Torga, de José Maria Moreiro, autor de um breve estudo dedicado à experiência africana em Torga titulado Torga e África, e de Clara Rocha, que realizou numerosos estudos da obra (autobiográfica) de Torga.

Com base nesses autores, o presente artigo configura-se, primeiro, a partir de uma breve contextualização da obra diarística torguiana. Segundo, continua-se com uma apresentação do universo torguiano, especialmente focado para a sua infância rural e adolescência em Minas Gerais, que foi o seu primeiro contacto com uma terra distante e marcadamente diferente quanto à paisagem de Portugal ou estilo de vida. A seguir passamos a fazer uma leitura das entradas diarísticas de Miguel Torga relacionadas com a sua estadia em Angola e Moçambique que esperamos entrelaçar com as teorias mencionadas a fim de conseguir os objetivos previstos. Ficam divididas em duas áreas gerais que denominamos a gesta africana e o olhar desimperial. $\mathrm{O}$ artigo fecha-se com as considerações finais que apresentam um sumário das noções adquiridas ao longo da análise das selecionadas entradas diarísticas.

\section{Torga e o Diário}

A obra literária de Miguel Torga começou em 1928 com a publicação do seu primeiro livro de versos, Ansiedade. Em total, é autor duma obra vasta, enraizada na estética modernista, repartida por diversos géneros: poesia, ficção narrativa, teatro, ensaio e produção autobiográfica. Neste percurso literário destaca-se a obra complexa A Criação do Mundo publicada entre 19371981 em seis volumes (Primeiro - Sexto Dia), com rasgos significativamente autobiográficos, e o Diário. O Diário, com dezasseis volumes, começado em 1932 e concluído com a última entrada em 1993 com o poema "Requiem por mim", é uma obra sumamente interessante, na qual o escritor discorre sobre a sua vida e os acontecimentos literários, culturais, políticos e sociais que marcaram a sua era. 
É tradicional dizer que a Península Ibérica não abunda em produção de textos autobiográficos em geral, embora a produção autobiográfica cresça e se diversifique notavelmente ao longo do século XX até o grau que conseguiu contrariar esta presunção, como observa a crítica contemporânea (Rocha 1992: 5; Figueiredo 2002: 57). Não obstante, é fato que a introdução das obras de caráter autobiográfico foi mais tardia em comparação com França ou Grão Bretanha. A posição do diário como género literário plenamente reconhecido e publicado é fixada nos primeiros decénios do século XX (Costa Teixeira 2008: 66). De qualquer forma, a entrada de Torga na cena literária coincide com o auge do género e a sua acomodação final na literatura portuguesa. Viegas Brauer-Figueiredo até menciona Torga como o primeiro diarista português (ibid., p. 15). Outros importantes diaristas da geração de Torga são José Régio, Sebastião da Gama ou Natália Correia. Contudo, quanto ao lapso de anos coberto e a quantidade de texto autobiográfico produzido, Torga pode-se comparar só talvez com Vergílio Ferreira e o seu Conta-Corrente.

É de sublinhar que o Diário de Torga forma parte integrante da sua obra literária, ultrapassando vastamente um possível experimento literário. Mesmo assim, os intentos de classificar esta obra, mesmo que o paratexto pareça ser claro, têm-se deparado com alguns obstáculos. Deve-se ao fato que a obra cumpre por uma parte com os usuais pré-requisitos que classificam uma obra como diarística, por outra apresenta uma curiosa inovação que puxa a conceção do diário mais além ${ }^{1}$. É, mais bem dito, um diário recriado, híbrido e multifacetado (Ponce de León 2005: 77), que contém inseridos numerosos poemas que saíram publicados em coletâneas independentes assim como os poemas inéditos, e vários contos e textos ensaísticos.

\section{O universo de Torga}

Ruiz Brown (2011: 50) que estudou o caráter poético do diário torguiano, destaca como dois constituintes essenciais da escrita torguiana os seguintes: "o nascer numa aldeia transmontana de pais camponeses; e o presenciar a escalada dos grandes fascismos europeus". Quanto ao primeiro, Torga enlaça com a conceção fenomenológica do lar que o considera ser um organismo estendido de nós mesmos, o nosso corpo prolongado, uma experiência que está inscrita no homem de forma indelével (Bachelard 1990: 53). Quanto à segunda, Ponce de León comenta: "À aguda consciência individual, presente ao longo de toda a obra de Miguel Torga, alia-se, inequivocamente, uma premente consciência social motivadora da assunção de posturas claras sempre postuladas no encalço da liberdade, que reivindica quer para si quer para outros" (ibid., p. 155).

Como é conhecido, Miguel Torga provinha duma família de camponeses humildes e teve uma infância rural dura começada durante a ditadura de João Franco, que lhe deu a conhecer a realidade do campo, feita de árduo trabalho contínuo na vinha e na roça. Após uma breve passagem pelo seminário de Lamego, viajou com treze anos para o Brasil, onde trabalhou na fazenda de um tio em Minas Gerais durante cinco anos (1920-1925) a capinar, guardar gado

1 Para mais sobre a escrita autobiográfica e especialmente o género de diário, recomenda-se por exemplo a obra de Isabel Vaz Ponce de Leão, Clara Rocha, Marcello Duarte Mathias, entre outros, no campo português. 
e apanhar café. Depois de regressar a Portugal, fez-se médico otorrinolaringologista. Provindo das apertadas condições rurais, passando pela experiência brasileira, e tendo assistido à subida de regimes ditatoriais, Torga mostra-se especialmente sensível às condições de opressão, falta de liberdade, intolerância e humilhação.

Este autor, cuja obra é tipicamente classificada como telúrica, ibérica, caracterizada pelo desespero humanista e crise religiosa, era também conhecido pelo seu amor por Portugal, especialmente pela sua terra natal, admiração pelo povo português, campo, mar, montanhas e florestas e também pela história célebre de Portugal, junto com as lendas que se criaram à sua volta. Como observa Dora Nunes Gago (2012: 85), é a partir dos anos cinquenta que se evidencia "uma emergência mais nítida do tema da portugalidade, da sua essência, num esforço de identificação com o país de origem”. A antropomorfização de Portugal, transfigurado no corpo e na alma do autor, é patente por exemplo no poema "Regresso", datado de 13 de junho de 1960 onde refere o seu país como "Pátria magra - meu corpo figurado..."

Como Torga reconhece no Diário, sente uma constante necessidade de viajar que lhe envia dum canto do país para o outro. Como refere no seu estudo Paulo Carvalho (apud Choupina 2012: 47), a maioria das viagens decorre em Portugal e $30 \%$ das viagens realizadas para além da pátria ocupam Espanha e as regiões raianas. Contudo, Torga fez viagens à cerca de duas dezenas de países em Europa, Américas, África e Ásia e continuou a viajar até uma idade avançada. Através da viagem adquire o sentido de formação e consciência da pátria já que "a terra não é igual em lado nenhum” (Torga 1999: 303). Aliás, é de salientar que as viagens de Torga nunca se limitam a um mero deslocamento físico; servem, ante tudo, como estímulos para realizar uma viagem intelectual e emocional, cujos estímulos são retrabalhados pelo autor na sua obra literária. Portanto, o ser e o estar de Portugal no mundo constitui um leitmotiv no Diário (Moreiro 1996: 47) e o conceito de ser português adquire uma nova dimensão em contacto com as colónias africanas.

Precisamente desde a união entre o desejo insaciável dos homens por descobrir novas terras e culturas, que Torga também comparte, e a tendência à introspeção e profunda reflexão, situamos o que Miguel Torga chamou "a necessidade de achar as Índias de dentro".

Nos diferentes exílios e nas várias errâncias dos portugueses, desde as navegações até a minha geração, houve talvez um traço comum, que foi o da redescoberta de Portugal a partir do contacto com outras realidades. Miguel Torga, que também falou na necessidade de «achar as Índias de dentro», disse-o melhor que ninguém. "Compreender", escreveu ele, "não é procurar no que nos é estranho a nossa projecção ou a projecção dos nossos desejos. É explicar o que se nos opõe, valorizar o que até aí não tinha valor dentro de nós. O diverso, o inesperado, o antagónico, é que são a pedra de toque dum acto de entendimento. (Alegre 2002: 35)

Esta brilhante metáfora expressa a vontade atemporal de atingir compreensão a si mesmo e aos outros, precisamente através de encontros com diferenças e opostos, já que estes podem chegar a constituir umas experiências reveladoras sobre nós mesmos, desde o ponto de vista mais amplo de nossa condição humana. Assim é de interesse seguir o modo como vai ganhando força nas páginas desta obra, a par da condição humana contrastada com o outro, a questão da identidade nacional, que funciona segundo Dora Nunes Gago como um fator de autognose (2012: 86). 


\section{A gesta africana}

Portanto, aos sessenta e seis anos de idade, no ano 1973, Torga empreendeu uma viagem a Angola e Moçambique. Nesse momento, ambos países, ou naquela altura províncias africanas, encontravam-se numa fase final e decisiva da luta pela sua independência de Portugal. Em Angola, as forças políticas e militares que visavam a transformação da colónia de Angola em país independente, iam desenvolvendo desde os anos cinquenta uma atividade intensa. A partir de 1961, os esforços unidos da UPA/FNLA, do MPLA e da UNITA desembocaram num combate armado contra Portugal, e entre 1961 e 1974 uma guerra estava a ferver entre os nacionalistas angolanos e as tropas portuguesas (Klíma 2008: 176-218). Em Moçambique, por sua parte, os movimentos formais de resistência uniram-se em 1962 para darem origem à FRELIMO, Frente de Libertação de Moçambique, oficialmente fundada a 25 de junho de 1962 (Klíma 2010: 180). Quando as negociações diplomáticas fracassaram, a FRELIMO resolveu tentar forçar o governo português a aceitar a sua independência através da guerra de guerrilha. O conflito armado durou cerca de dez anos terminando com os Acordos de Lusaka a 7 de setembro de 1974 (idem, p. 204-206). Quer dizer, a Guerra Colonial (1961-1974) estava a culminar em ambos os países durante a visita de Torga em 1973, que chegaram a adquirir a sua independência dos anos mais tarde; Moçambique a 25 de junho de 1975 (ibid, p. 269) e Angola a 11 de novembro de 1975 (Klíma 2008: 315).

As razões porque o poeta resolveu visitar Angola e Moçambique são provavelmente várias. É um fato que o poeta estava fascinado pela Era dos Descobrimentos e pela presença dos portugueses além do território europeu, como se deduz do seu diário. Os descobridores dos séculos XV e XVI são figuras de frequente referência nas entradas diarísticas, pois nota-se distintamente que também a literatura de viagens medieval está muito valorada por ele. O historiador Rui Ramos, citado por Lucinda Canelas, opina que boa parte do encanto que este período provoca, é dado pelo fascínio da aventura, da proeza, da afirmação militar, das grandezas dos colonizadores portugueses na história, comentando:

Isso continua a fascinar, mesmo quando nós não gostamos de o confessar. Essas são as grandes histórias que podemos contar. A grande história não é a da formação do Bloco Central entre 1983 e 84, com Mário Soares e Mota Pinto. A grande história é dobrar o cabo da Boa Esperança, a grande história é chegar à Índia, a grande história é conquistar Goa, a grande história é defender o Brasil dos holandeses... A grande história é a das aventuras, com emoção, a história que abre horizontes. As aventuras são matéria de filme e de romance, é a aventura que as pessoas procuram, verem na história algo de diferente do que é o quotidiano (Canelas 2012: 28).

De fato, traços de semelhante visão romântica podem-se sentir na entrada na qual Torga relata a sua "descoberta” pessoal de África: “[...] Angola! Não foi certamente a mesma emoção que sentiu um marinheiro de quinhentos ao pisar estas paragens mas quase" (1999: 1246).

Outro motivo é mencionado por José Maria Moreiro que adere aos motivos também o engajamento social e político do poeta: "Miguel Torga vai também a África como médico, disposto ao levantamento de um diagnóstico sociopolítico profundo, num momento chave de tão grandes incertezas nacionais" (ibid., p. 22). Assim, à decisão de seguir os trilhos dos descobridores 
para ver o resultado da expansão física e cultural de Portugal suma-se a procura do sentido de participação e o engajamento do poeta.

Finalmente, pode-se encontrar um terceiro objetivo, um objetivo permanente, íntimo e obsessivo de Miguel Torga, "continuar à procura de si mesmo, mesmo nos outros" (ibid., p. 61), ou, como formula esta ideia na sua obra Portugal, realizar "a grande façanha da renovação interior" (1986: 138), que encontra eco no afã de "achar as Índias de dentro" mencionado mais acima.

As vivências africana ficam recolhidas no Diário XII que começa, como tradicionalmente todos os volumes do Diário, com um poema, "Viagem", neste caso, datada de Coimbra, 17 de maio de 1973. A viagem termina a 12 de junho de 1973, novamente como um poema, "Breve Adeus", provido da referência de A voar para Lisboa, 12 de Junho de 1973. Em total, Torga permanece em África como turista quase um mês. África serve-lhe com o material para escrever, além de "Viagem" e "Breve Adeus", poemas “Diogo Cão" e "Embondeiro". Moreiro (ibid., p. 63) adere a este ciclo de poemas escritos e/ou inspirados em África também o poema "Regresso"; mesmo que esteja escrito já em Coimbra terminada a viagem (datado de 20 de junho), é claramente entrelaçado com a recente viagem. Como Moreiro ressume, "em todas estas páginas que Torga dedica a África, e não serão as únicas, destaca a guerra, a desconfiança e ódio desatados, o pressentimento da perda das colónias." (ibid, p. 63).

Com intuito de explorar os lugares visitados até o máximo, Torga visita numerosas cidades e sítios de interesse, galerias de arte local, que o chocam com as suas cores vivas, "revelações agressivas de não sei que traumatizada memória ancestral” (ibid., p. 1259), sai de caça, caminha pelo deserto, observa a gente e encontra-se com representantes de movimentos independentistas (ibid., p. 1258-1259).

Já logo no início da sua estadia o poeta chega a observar que não consegue compreender plenamente o país e a sua realidade, que fica para ele sempre desconhecida, e custa-lhe adaptarse a este novo e desconhecido meio. O poeta comenta a respeito:

Numa aplicação esforçada, tento compreender este chão em si mesmo, especificamente, mas os sentidos refilam, inseguros fora dos seus padrões habituais - transmontanos, alentejanos ou beirões. E por mais que não queira, sinto-me nele intruso, rejeitado, excluído [...] (ibid., p. 1247).

A impressão de sentir-se intruso repete-se para o poeta em Moçambique quando, como um caçador ativo, vá caçar em Gorongosa encontrando ali uma povoação nativa. Mais tarde comentou ter-se sentido muito incómodo. "Entre mim e e aqueles irmãos de espécie abria-se um abismo intransponível com quinhentos anos de largura. Desse as voltas que desse, eu era ali um inimigo." (ibid., p. 1256).

Quer dizer, o poeta concluiu que por mais se esforçar, o lugar e a cultura do local visitado não lhe eram próprias. Este fio de reflexões sobre a sua participação ou exclusão relativamente à cultura que o envolve remete para o tema de identidade cultural e nacional. Como explica Cidália Viegas de Carvalho, a formação e a pertença a uma nação configura-se como uma realidade compósita e multifacetada, constituída por um leque de elementos fulcrais como são o território, povo, estado, constituição, língua, história, mitos, arte e religião. Adverte que por seu lado, também se argumenta que "a nação moderna assenta numa base imaterial, alicerçada 
num sistema coeso de representação simbólica e sociocultural, e, em certa medida, por uma componente afetiva" (2014: 346).

Torga sintoniza com este conceito compósito da nação numa entrada de setembro de 1941: “[...]Uma nação passou a ser uma realidade geográfica e humana, com língua própria, costumes próprios, alfândegas próprias, e, acima de tudo, com um imponderável biológico e social, que, por mais que o estrangeiro faça, nunca chega a entender [...]” (ibid., p. 149).

O único lugar no qual encontra sintonia entre o local e o português é para ele a Ilha de Moçambique onde se misturam, segundo o poeta, duma forma insólita mas aparentemente natural os habitantes dos povos autóctones, as cubatas indígenas, as capulanas coloridas e os turbantes com as fortalezas, igrejas e palácios dos colonizadores portugueses. Considera o lugar como um exemplo duma colonização bem-sucedida, a concentração do melhor "do génio lusíada" e admira a forma com que se entrelaçam e perpassam as diferentes culturas, fés e costumes. Torga sente-se neste meio cómodo e à vontade, que lhe faz comentar: "tenho a impressão de surpreender um acto de imaginação da pátria” (ibid., p. 1257-1258).

Outra interessante vertente de reflexões decorre da paisagem e natureza africanas. Torga, cuja obra e vida pessoal é caracterizada pela íntima união com o chão, e um diálogo com a natureza, depara com especial interesse a paisagem e a flora. Ele compara a natureza africana com a brasileira que conheceu intimamente durante a sua meninice e mais tarde diversas viagens de trabalho ou lazer. Estabelece uma diferença marcada comentando que enquanto no Brasil há uma rica variedade e abundância vegetal, em África “a clorofila deu lugar à proteína” (ibid., p. 1255). Observa, ainda, os diferentes animais da savana africana e fica deslumbrado perante o deserto de Moçâmedes em Angola que o encanta pela sua imensidão e silêncio, vendo nele a "imagem física da eternidade morta" (ibid., p. 1251). Quanto à flora, em numerosas ocasiões volta a mencionar o embondeiro que o fascina. Em um primeiro momento, não tem muita apreciação por ele e refere-se a esta árvore como a "o aborto da flora, a vergonha do reino vegetal" (ibid, p. 1248). Não obstante, parece que depois apieda-se do embondeiro e dedica-lhe um poema que leva o mesmo nome.

Tete, 5 de Junho de 1973.

EMBONDEIRO

Por mais que mude a luz

De cada panorama,

O teu vulto persiste

Em ser a imagem triste

Da tristeza africana. (ibid., p. 1257)

Neste conciso poema que utiliza versos hexassílabos condensam-se emoções e símbolos. A figura central, o embondeiro, é tradicionalmente considerado como um forte símbolo da cultura africana e uma árvore sagrada (Marques 2012: 10), que inspira poesias, ritos e lendas. Sendo uma árvore majestosa, pode atingir até trinta metros, possui um caule gigante e uma longevidade considerável. Destaca-se também pela sua capacidade de armazenamento de água, que representa a vida nas zonas secas.

No nosso ver, podemos considerar a árvore personificada como alegoria para a situação pela qual Angola, à época, passava e pelas quais ainda pode passar, como o expressa o primeiro e 
segundo verso. Mesmo forte e resistente como o embondeiro, encontra-se presa pelos grilhões da sua situação social e política, e por tanto, na ótica da voz lírica, encerra sempre certo grau da pena e tristeza.

\title{
5. O olhar desimperial
}

\begin{abstract}
África era um privilegiado e antigo destino que, em boa parte e juntamente com as restantes colónias lusas noutros continentes, havia inclusivamente dado origem em Portugal a uma teoria política: a do atlantismo. A política portuguesa, sobretudo durante a ditadura salazarista, apoiava os seus argumentos, até para justificar o seu isolacionismo obrigatório, no carácter pluricontinental que o Atlântico e as possessões ultramarinas lhe conferiam. (Moreiro 1996: 31)
\end{abstract}

Moreiro conecta neste trecho o contexto histórico com um importante fator na biografia do autor. Estado Novo, envolto numa estratégia atlantista, disseminava a noção de Português Ultramarino $^{2}$. Como explica Rui Ramos, o tema da expansão foi, no século XX, muito frequente em relação com a colonização de África, sublinhando, que o regime de Salazar não foi o único a servir-se ideologicamente dos Descobrimentos, prática que datava já da monarquia constitucional e da I. república ${ }^{3}$.

Como é sabido, Torga sempre se opôs ao regime e defendia no primeiro lugar a igualdade de direitos e a liberdade mantendo-se independente de jogos partidários a amarras políticas. Explorando os lugares visitados e conhecendo a realidade africana mais de perto, Torga dá-se conta de que a colonização não foi só um sucesso da cultura lusófona. Em Lobito observa um cenário pouco animador.

Lobito, 24 de Maio de 1973 - Quantro instantâneos: a aridez dos montes circundantes, Camões entronizado num pedestal, o forte de Catumbela e o empório comercial de Cassequel. A terra, outrora coberta de vegetação, esterilizada pela incompetência sanitária que incendiou o mato para debelar a doença do sono; o épico a enfunar o peito heróico diante do analfabetismo indígena; a força de ocupação fortificada e celebrada; e a exploração colonial com as letras todas (ibid., p. 1250).

Mais a propósito de colonialismo, sobressaem vários comentários de Torga nos quais distingue entre o colonialismo realizado no Brasil e em África.

2 Em 1951, Portugal designou as colónias como territórios ultramarinos, abolindo assim o conceito de "Império Colonial Português" e dando passo ao Conceito Ultramarino Português que definia que todas as províncias ultramarinas eram uma parte integral e inseparável de Portugal. O Estado Novo assim procurava manter as suas possessões coloniais, consideradas pelo regime uma das fontes do prestígio e orgulho nacional e acalmar as vozes do quadro político internacional que reclamavam maior autonomia para os territórios sob a administração portuguesa (Klíma 2010: 171).

3 Lucinda Canelas, autora do artigo “Série Mar Português: Continuamos esmagados pelos Descobrimentos?” menciona as celebrações do quinto centenário do infante D. Henrique em 1894 e a comemoração da viagem do Gama em 1899, organizadas pela monarquia constitucional; comemorações em 1915, ainda que modestas, realizadas pela república, dos 500 anos da conquista de Ceuta. Opina, em sintonia com Rui Ramos, que no tocante aos Descobrimentos, há uma continuidade entre os regimes: "Tudo isso, obviamente, deixou um lastro que explica também que o regime democrático, quando teve oportunidade de fazer as suas primeiras grandes comemorações históricas, se tenha focado nos Descobrimentos em 1998, com a exposição internacional de Lisboa." (ibid., p. 27). 
Não há dúvida: o português foi incapaz de repetir nestas paragens africanas o milagre brasileiro. Lá, enraizou-se; aqui, não. Certamente porque lá o senhor e o escravo eram ambos emigrados e colonizadores. [...] Aqui, o branco foi e continua a ser intruso. Não houve comunhão de corpos e almas. [...] (ibid., p. 1249).

Torga basicamente sugere dois tipos de colonialismo português; o primeiro, supostamente positivo, teve lugar no Brasil e o segundo, predominantemente negativo, em África. Esta distinção pode resultar das lembranças da sua adolescência passada no Brasil, descrita praticamente sempre de forma positiva que lhe faz formular esta hipótese peculiar. Como observa Alfeu Sparemberger, as referências ao Brasil são frequentes na obra torguiana referindo-se o autor ao Brasil em várias obras literárias. Por exemplo, O Segundo Dia da sua autobiografia A Criação do Mundo é dedicado a sua experiência no Brasil. O experiencing I do menino e o narrating I do narrador adulto misturam vozes em admiração pelo Brasil e as terras tropicais. Também o Diário VII traz o Brasil como tema central, resultado de uma segunda visita ao país, em 1954. Finalmente, o Brasil aparece também em Traço de União (1955), e sempre é lembrado com admiração e afeto (2012: 13-15).

José Maria Moreiro opta por usar a mencionada citação para fazer mais um cometário relevante. Opina que a sua observação revela "sintomas segregacionistas e a resistência frontal do nativo perante o seu colono, mas no preciso momento em que já está conhecendo na sua mente um decidido desejo libertador" (ibid., p. 50).

Ao visitar a cidade de Nova Lisboa, Torga reivindica independência para as colónias portuguesas, um país construído com os esforços unidos dos habitantes nativos liberados do seu jugo colonial.

[...] Nova Lisboa, porquê? Carmona, a que propósito? Sim, um próspero país futuro, construído com amor e suor do Zair ao Cunene cada habitante a semear e a colher os frutos agridoces da vida por conta própria e não por conta alheia. Um país a caminhar unitariamente, e não uma colónia salteadamente a tropeçar (ibid., p. 1254).

Por conseguinte, evidencia-se a priori o tópico da oposição entre o apogeu colonial do passado e a triste realidade do presente. Quer dizer, a gesta dos Descobrimentos adquire sérios buracos causando a Torga uma forte desilusão, quer em Angola quer em Moçambique, pela falta de humanidade e respeito pela diferença. Afinal, o autor não encontra grandes obras justificadoras da presença portuguesa em África. Verifica, nas suas palavras, a "falência civilizadora" (ibid., p. 1260) dos portugueses que "deixou passar a oportunidade de fomentar as várias maneiras de ser português, impondo-se e gerando ódios por uma guerra vã” [...] (Ponce de Leão 2005: 174). O poema que Torga dedica a Diogo Cão, o seu "comprovinciano", como escreve, louva o navegador por aventurar-se tão longe e, especialmente, por ser "quem só descobriu e nada conquistou4".

Já antes e mais ainda depois de voltar de África Torga seguia os acontecimentos em Angola e Moçambique e expressava-se sempre contra todas as injustiças ali ocorridas ora no presente

4 "Santo António do Zaire, 23 de Maio de 1973. DIOGO CÃO /A pura glória tem/A humilde singeleza do teu nome. /E cresce eternamente,/ Como um caule imortal,/ No fuste do padrão/ Que a tua inquietação/ Ergueu/ Nestes confins do mundo onde chegou./ Limpo brasão de quem só descobriu/ E nada conquistou" (1999: 1250). 
ora no passado. perdeu-se o exaltado espírito lusíada nas relações entre brancos e negros. Em Cela, repara nas relações entre colonos e nativos e conclui as suas observações com um amargo comentário. Baseando-se no que vê, infere que o indígena é "uma máquina útil que no fim do seu trabalho recebe o seu dinheiro" (1999: 1249), ficando excluído da família e segregado. Neste contexto destaca um pequeno episódio ao qual assistiu decorrido entre a filha da família dos seus hóspedes e duas criadas da família. As criadas interrompem um jogo da menina que, enfuriada, lhes insulta gritando “Pretas! Pretas!” A resposta da criada mais idosa faz pensar ao poeta. “[...] «Bem sei que sou preta» é exatamente o oposto de «bem sei que sou branca». E há quinhentos anos que as duas etnias se excluem mutuamente nos termos estritos deste dilema bárbaro" (ibid., p. 1248).

Por outro lado, Torga consegue olhar para o futuro, e admira as possibilidades de África assim como a sua frescura. É vista como um organismo vivo, com potencial para o futuro, embora talvez agressivo demais para o já sossegado poeta.

A voar para Luanda, 10 de Junho de 1973 - A mesma sensação da outra travessia. Esta África tem qualquer coisa de embrionário, de protoplásmico, de massa a levedar. Tudo nela me parece informe, indeciso, os rios ainda sem leito, os montes ainda sem equilíbrio, os seres ainda sem destino, a natureza ainda sem paz. Olho, e tenho a sensação de ver uma imensa placenta (ibid., p. 1259).

A despedida que faz do continente africano é emocionante e aparece no poema "Breve Adeus”, onde África é chamada por “continente solar” e fremente coração de terra.

A voar para Lisboa, 12 de Junho de 1973.

BREVE ADEUS

É um adeus que te digo num poema,

Continente solar,

Grande e fremente coração de terra!

É um adeus de poeta atribulado,

Que dos longes da História

E na carne dos seus

Veio ver a negrura

De um pesadelo.

É um adeus que, ao dizê-lo,

Se coalha nos olhos marejados,

E dói tanto

Que não pode ter versos demorados,

Que não pode durar além do pranto.

Como se deduz, o poeta não fica indiferente ante o encontro com África e o seu pulso de vida. Acontece, porém, que o poeta regressa a Lisboa afligido por constatar que Portugal, no encontro com as culturas africanas não celebrou só união e irmandade. Achou ali um distanciamento cultural marcado, contrariamente ao que se deu no Brasil ou, melhor dito, no Brasil da sua infância e cuja imagem conserva na mente. 
Mesmo assim, depois de regressar a Portugal Torga segue os acontecimentos em África com muito interesse e reflete-os frequentemente nas suas anotações diárias. Não deixa de lado nem o destino dos retornados ${ }^{5}$ todas a mudanças políticas das que chega a saber. A 27 de julho de 1974 pronunciou-se sobre o momento histórico chave que significa a finalização do processo da descolonização da seguinte forma:

Vamos dar finalmente independência aos povos colonizados. Uma independência que sem dúvida lhes irá custar cara, mas não há nenhuma que seja barata. Depois desse acto necessário e imperioso, Portugal ficará reduzido à tal nesga de terra debruada de mar. É a História que o exige, e oxalá que o destino também. Oxalá que ele, depois de tantos séculos de dispersão e perdição, nos queira reduzidos ao núcleo matricial para que, assim recuperados, possamos iniciar nova aventura (ibid., p. 1281).

O anseio de dar liberdade às colónias portuguesas é patente nestas palavras, embora o poeta reconheça que haverá adversidades para superar. É verdade que por outra parte Torga expresse algumas preocupações pela redução do território português, mas sempre com esperança para o futuro e que esta inevitável realidade se torne positiva para Portugal. A nação obterá assim uma oportunidade de voltar à sua essência e renovar-se desde o interior até encontrar as Índias ali, em vez de procurá-las fora.

\section{Considerações finais}

Chegando ao final do nosso artigo, podemos sumarizar as noções fundadas na leitura das selecionadas entradas do Diário de Miguel Torga e, neste caso, especialmente pertencentes ao Diário XII que encerra as impressões do autor da viagem ao continente africano. Sendo esta vertente temática da obra torguiana pouco explorada, esperamos contribuir com o nosso artigo para melhor entendimento desta criação altamente complexa e densa que é o Diário.

Começamos com o intuito de explorar a temática baseada na experiência de Torga em África para onde partiu a fim de conhecer a pátria além dos confins ibéricos, cheio de desejo de seguir os trilhos dos descobridores portugueses medievais, e também para ver o processo da luta pela independência e o processo da descolonização, em plena força durante a visita do poeta em 1973. O objetivo do artigo, portanto, assenta nas seguintes direções.

Iniciamos com uma breve introdução à diarística de Miguel Torga. De fato, Torga levou a cabo uma obra insólita, de considerável dimensão que cobre um lapso de tempo impressionante. O caráter poético do diário inteiro ficou comprovado também neste ciclo temático com cinco poemas escritos durante a estadia do autor em África e incluídos no diário.

A seguir, passamos a apresentar o universo torguiano, especialmente focado para a sua infância rural e a adolescência que decorreu na fazenda do seu tio em Minas Gerais. Precisamente o contacto com o Brasil significou uma experiência chave para Torga oferecendo assim início à procura de toda a vida - a de encontrar a sua identidade de português. Ao mesmo tempo, o Brasil converteu-se no padrão com o qual seriam comparadas as vivências posteriores em África. 
Portanto, o relato das viagens que Torga realizou no estrangeiro é uma oportunidade para deter-se no confronto e comparação de espaços físicos e culturais. Como adverte Rocha, quase sempre neste caso a terra portuguesa "funciona como bitola e padrão" (1992: 221).

A viagem a África serve para procurar convergências e divergências com Portugal e invocar a "essência" de uma nação, cuja singularidade se traduz na sua relação com o Outro. Assim, tentamos mostrar como aflora a questão da identidade nacional através do estabelecimento da alteridade do elemento africano.

Além de grande viajante, Torga foi conhecido pelos estribos arcaicos da identidade e memória da nação portuguesa. Ao longo do Diário podemos encontrar várias alusões ao antigo Portugal Ultramarino, famosos descobridores portugueses, mito de descobrimento, ele foca a expansão de Portugal, e em geral interessa-se pelos traços portugueses no mundo. Relativamente à História e ao passado, Torga inicialmente parte com uma visão maioritariamente positiva e espera ver em África principalmente o lado favorável da expansão portuguesa. Não obstante, o confronto problemático com a realidade o faz assumir uma posição contraditória, reconhecendo paralelamente o eufórico e o disfórico da história. Embora sempre aceitando a importância dos mitos nacionais nas quais se funda a identidade nacional (Viegas de Carvalho 2014: 346), o poeta revisita o seu legado atual.

Além da procura da identidade individual/coletiva comentamos como Torga percebe a guerra que singrava naquelas paragens, bem como o processo de descolonização. Neste respeito foi importante salientar que o Diário no seu total contém uma forte componente de responsabilização social. Toda a obra de Torga é mostra da demanda de solidariedade, liberdade e respeito mútuo, encaminhando-se assim para um humanismo dominante que abrange a sua obra literária toda, não exceptuando o Diário. Em primeiro lugar, ele repara no ar de desconfiança do povo autóctone para com os estrangeiros europeus, neste caso personificados nele. Em geral, constata as prevalecentes relações segregacionistas entre colonos e indígenas, excluídos estes do núcleo familiar, como Torga sensivelmente nota quando convidado a visitar uma respeitada família angolana. É notável neste respeito, até que ponto a experiência da vida no Brasil servelhe para apreender a realidade angolana e moçambicana.

Em fim, gostávamos de concluir que ler as páginas relativas à viagem de Torga a África foi uma aventura sumamente interessante. Num espaço tão reduzido, em comparação com a obra inteira, afloram temáticas muito diversas e encontramo-nos com reflexões relevantes que vão revisitando as convicções originais do diarista criando espaço para um entendimento alterado da realidade africana, e trazendo noções inesperadas sobre a realidade portuguesa e a do sujeito mesmo. 


\section{Referências bibliográficas:}

\section{Ativa:}

Torga, M. (1986) Portugal. Coimbra: Gráfica de Coimbra.

—. (1999). Diário Vols. IX a XVI (1964-1993) (2 ed. integral). Coimbra: Publicações Dom Quixote. .(1999). Diário Vols. I a VIII (1941-1959) (2ª ed. integral). Coimbra: Publicações Dom Quixote.

\section{Passiva:}

Alegre, M. (2002). A arte de marear: Ensaios. Lisboa: Publicações Dom Quixote.

Bachelard, G. (1990). Poetika prostoru. Bratislava: Slovenský spisovateĺ.

Brauer-Figueiredo, M. de F. V., \& Hopfe, K. (2002). Metamorfoses do Eu: O Diário e outros Géneros Autobiográficos na Literatura Portuguesa do Século XX. Frankfurt am Main: TFM.

Brown, S. M. R. (2011). O carácter híbrido dos diários de Miguel Torga: A predominância do poético. Tese (pós-graduação em Literatura Portuguesa). São Paolo: Universidade de São Paolo. <http://www.teses. usp.br/teses/disponiveis/8/8150/tde-19092011-102712/en.php>

Canelas, L. (2012). Série Mar Português: Continuamos esmagados pelos Descobrimentos? Público, 26 setembro, 26-28. <http://www.saer.pt/up/UPLOAD-bin2_imagem_0564712001349365465-570.pdf>

Carvalho, C. V. de. (2014). Memória e Mito dos Descobrimentos na Literatura do Século XX. Forma Breve, 11: Microficção. Aveiro: Universidade de Aveiro, pp. 345-351. <http://revistas.ua.pt/index.php/formabreve/article/download/3136/2904>

Carvalho, P. (2012). Geografia e paisagem no universo literário de Miguel Torga. A Cordilheira Central através do Diário (1932- 1993). Revista da Faculdade de Letras - Geografia, III (1), 45-58. <http://ler. letras.up.pt/uploads/ficheiros/10556.pdf>

Gago, D. N. (2012). "Avivo no teu rosto, o rosto que me deste": espelhos da identidade nacional no Diário de Miguel Torga. Moderna språk, 1, 85-96. <http://ojs.ub.gu.se/ojs/index.php/modernasprak/article/ viewFile/1183/1022>

Klíma, J. (2008). Dějiny Angoly. Praha: Nakladatelství Lidové noviny. . (2010). Dějiny Mosambiku. Praha: Nakladatelství Lidové noviny.

Marques, M. L. L. (2012). Maurício Gomes e a (re)invenção da poesia Angolana. Cadernos Imbondeiro, 2 (1), 1-14. <http://periodicos.ufpb.br/ojs/index.php/ci/article/view/14166/8767>

Moreiro, J. M. (1996). Miguel Torga e África. Lisboa: Universitária.

Ponce de Leão, I. V. (2005). A Obrigação, a Devoção e a Maceração. O Diário de Miguel Torga. Lisboa: Imprensa Nacional - Casa da Moeda.

Rocha, C. C. (1992). Máscaras de Narciso: Estudos sobre a literatura autobiográfica em Portugal. Coimbra: Almedina.

Sparemberger, A. (2015). O Brasil na visão de Miguel Torga. Revista Querubim - revista eletrônica de trabalhos científicos nas áreas de Letras, Ciências Humanas e Ciências Sociais, 18, 13-19. <http://www.uff.br/ feuffrevistaquerubim/images/arquivos/zquerubim_18.pdf>

Teixeira, C. M. da C. (2008). “Escrever-se” e/ou “Outrar-se”. Escrita e revelação em Páginas do diário íntimo de José Régio. Dissertação de mestrado. Vila Real: Universidade de Trás-os-Montes-e-Alto-Douro. $<$ https://repositorio.utad.pt/handle/10348/158> 
